\title{
The Magic Appeal: Fantasy Elements in the Twilight Series
}

\author{
WANG Hui \\ China Youth University of Political Studies, Beijing, China
}

\begin{abstract}
The Twilight series by Stephanie Meyer, including Twilight, New Moon, Eclipse, and Breaking Dawn, has won multiple awards and is the most popular among young adults. The series is both an unbelievable romance of a 17-year-old girl and a 104-year-old vampire and an exquisite fantasy of the supernatural and impossible. Typical fantasy elements exploited in the series, including the existence of supernatural creatures, fulfillment of human desires, depiction of the Secondary World, and imagination of a Utopian society, play a significant role in achieving its magic appeal to the readers worldwide. Thus, the present paper attempts to explore how such irresistible attraction is made possible by employing these fantasy elements.
\end{abstract}

Keywords: the Twilight series, fantasy, the Secondary World, Utopia

\section{Introduction}

Described by The New York Times as a literary phenomenon, American writer Stephanie Meyer's Twilight, a series of four vampire-themed fantasy romance novels including Twilight, New Moon, Eclipse, and Breaking Dawn, has gained enormous commercial success and immense popularity among teenagers and young adults ever since the release of its first book in 2005. Spending over 235 weeks on The New York Times Best Seller list for Children's Series Books, the series has been translated into 38 different languages and sold over 120 million copies globally.

The Twilight series is both a fascinating romance of Bella Swan, a regular teenage girl, and Edward Cullen, a gorgeous104-year-old vampire and a breathtaking thriller full of intense confrontations in the supernatural world of vampires and werewolves. Frequently compared to The Lord of the Rings and Harry Potter, the magic appeal achieved by the fantasy elements in the series has been widely acknowledged. The Daily Telegraph hailed it as the "spiritual successor to Harry Potter" having filled the hole left by Harry Potter while Rebekah Bradford of The Post and Courier stated that the series has a "huge crossover appeal much like the Harry Potter books before them". Despite this, the serious studies of how the typical elements of fantasy are exploited are very rare. Thus, this paper intends to elaborate the identifying traits of fantasy embodied in the series and reasons for their irresistible appeal to the reader.

\section{Supernatural Powers and Impossibilities}

Fantasy is defined, in Oxford Dictionary of Literary Terms, as any kind of fictional work that describes "imagined worlds in which magical powers and other impossibilities are accepted" (Baldick, 2008, p. 125), including a wide range of literary genres from fairy tale to science fiction. As a distinct literary genre, fantasy may be best regarded as a fiction evoking wonder via elements of the supernatural or impossible (Mathews,

WANG Hui, associate professor, Foreign Language Department, China Youth University of Political Studies. 
1997, p. 2). Twilight, as commented by The New York Times, "seethes with the archetypal tumult of star-crossed passions, in which the supernatural element serves as a heady spice" (Meyer, 2007, back cover).

The first and foremost supernatural element in the series is the existence of the vampire which has turned an otherwise common high school love story into an intriguing suspense full of the protagonists' intense inner struggle, the inherent danger in this unorthodox love and the creepy terror caused by violent confrontations in the vampire world. The vampire has long been the theme of literary works since ancient Greek and Roman mythology and inspired numerous horror novels in which Bram Stoker's Dracula is the most famous and lasting example. Unlike the typical devil image of vampires in the previous literary works, Edward Cullen's family is a group of vampires who have the dazzling appearance, vegetarian diet feeding only on the animal blood, and caring humanity. Besides, some members of the Cullens even have supernatural talents like Edward's mind reading and Alice's seeing the future.

The second element of the impossible is the involvement of werewolves in the local Indian tribe, Quileute teenagers who are invulnerable to conventional injuries due to their super healing abilities and can shape-shift into giant wolves protecting their tribe and reservation from the vampire, their natural enemy. The werewolf is a widespread concept in European folklore which has gained popularity since the 15th century becoming a prolific source of horror stories, of which the most famous one is Marryat's The White Wolf of the Hartz Mountains (Cuddon, 2014, p. 341). Based on the Quileute legends, the depiction of the werewolf in the series has gone from traditionally malevolent demons to heroic tribal warriors, who actually are shape-shifters taking the form of a wolf and who inherit wolf traits from their parents rather than being infected through bites.

Modern fantasy, as a literary genre, is closely related to and frequently draws on the inexhaustible reservoir of myths, legends, fairy tales, and folklores worldwide (Mathews, 1997, p. 2). Inspirations from the age-old mythology and folklore combined with the author's own creative imagination have made the images of vampires and werewolves in the series both mysterious and distinctive. Such supernatural or impossible elements are not simply described as alien or frightening creatures, but rather magical and wonderful existence with which the reader feel at home. It is this more than anything else that distinguishes the Twilight series from a common ghost and horror story where the supernatural is left entirely alien (Manlove, 1975, p. 158).

\section{Fulfillment of Human Desires}

The word fantasy can also be used as a psychological term referring to a sequence of mental images, such as a daydream, usually fulfilling a wish or psychological need. In this sense, fantasy can be seen as people's unconscious response to the storehouse of fears and desires which "frequently find their most resonant surface manifestations in fantasy literature" (Armitt, 2009, p. 3). Likewise, the Twilight series just speaks out people's aspirations for immortality, power, affection, and self-realization in an effective and distinctive way.

The vampire and werewolf in the series both have what human beings long for-immortality and youth. Once made immortal, the vampire is frozen at the age of transformation and will live perpetually. The two oldest vampires, Stefan and Vladimir from the Romanian coven were born before 1000 B.C.. The werewolf also will not age if they keep transforming. The existence of such possibilities best satisfies people's desires for longevity and youth while removing their fear of death and aging.

Being able to possess the magical power might be a common scene in most people's childhood dreams, be it the ability to fly without wings or to become invisible at will. Our childhood dreams seem to come true in the series where vampires with nearly indestructible bodies can run faster than 100 miles per hour, lift objects 
hundreds of times their own weight effortlessly, and have perfect recall as well as indefinite time since they do not need to sleep or rest. Many of them even have innate abilities such as mind-reading, precognition, and empathy.

Love, the eternal theme of literature, finds its grandest expression in the Twilight series. The love between Bella and Edward, which has stood the test of lust, separation, and death, represents the ideal state of affection people could ever expect. In Eclipse Bella's mother was impressed by their burning passion and commented Bella oriented herself around Edward without even thinking about it like satellite moving around magnets while Edward behaved like he was about to throw himself in front of a bullet to save Bella. Their affection for each other might be best expressed in Edward's words in New Moon:

Before you, Bella, my life was like a moonless night. Very dark, but there were stars - points of light and reason... And you shot across my sky like a meteor. Suddenly everything was on fire; there was brilliancy, there was beauty. When you were gone, when the meteor had fallen over the horizon, everything was black. Nothing had changed, but my eyes were blinded by the light. I couldn't see the stars any more. And there was no more reason for anything. (Meyer, 2006, p. 514)

Self-realization is a common thread running through almost all fantasy fictions for teenagers and young adults, where protagonists deal with stakes possibly as large as the fate of the world and meanwhile they also come into their own and learn who they truly are. It is not uncommon that these protagonists begin their stories in the fantasy as outcasts, orphans, or people on the fringe of the society, later discover they possess some supernatural abilities and eventually become superheroes who overcome evil or achieve justice. In Twilight, when Bella just arrived in Forks, she thought she exiled herself and was worried that she would be "the new girl from the big city, a curiosity, a freak" (Meyer, 2005, p. 10). Before her transformation into a vampire in Breaking Dawn, she was often portrayed as extraordinarily clumsy, without the necessary hand-eye coordination to play sports or even dance. Besides, Bella did not relate well to her peers in Phoenix or Forks feeling a bit out of sync with everyone. She even doubted there was a glitch in her brain. However, after her transformation, she became the superhero, shielding all her families and friends from the mental attack of the Volturi, and finally found her place in the world, as she put herself:

After eighteen years of mediocrity, I was pretty used to being average. I realized now that I'd long ago given up any aspirations of shining at anything. I just did the best with what I had, never quite fitting into my world. So this was really different. I was amazing now - to them and to myself. It was like I had been born to be a vampire. The idea made me want to laugh, but it also made me want to sing. I had found my true place in the world, the place I fit, the place I shined. (Meyer, 2008, pp. 523-524)

According to Armitt (2009), a basic fantasy identification is "the outward projection of our collective inner desires" (p. 118). Like other literary fantasies, the Twilight series intends to explain the utterly inexplicable, our greatest fears and desires, through a narrative.

\section{The Secondary World}

The Secondary World theory was proposed by Tolkien (2001) who argues in his "On fairy stories" in Tree and Leaf that the story maker is a sub-creator creating the "Secondary World inside which the green sun will be credible" (p. 49). Unlike the Middle Earth in Tolkien's Lord of the Rings, the Secondary World of vampires and werewolves in the Twilight series co-exists with the primary world like a world-within-a-world which the mundane inhabitants of the primary are unaware of. 
In the Secondary fantastic world, everything goes on in accordance with its own laws. It is this "inner consistency of reality" (Tolkien, 2001, p. 123) that makes the creation of the Secondary World successful. The vampire world in the Twilight is profoundly affected and strictly governed by the central law that all vampires have to keep the secret of their existence and protect their anonymity. This has shaped the most common lifestyle of vampires that is nomadic, most of them never truly settling in one permanent place, established the authority of the Volturi whose main function is to punish those having violated this law, and resulted in the vampires' collective intolerance of immortal children who cannot be disciplined and often easily arouse the notice of human beings. On the other hand, the werewolf world evolves around the Quileute wolves' sacred duty of protecting the human tribe from their natural enemy, vampires. Their immortality, physical features including strength, speed and quick healing, social structure as well as telepathic communication in the pack are all the necessary guarantees of fulfilling their duty.

The Secondary World, according to Tolkien, can offer the reader both the escapist pleasure and emotional consolation. In the Secondary World, the reader can escape everyday monotony of living by experiencing things impossible and find fairness and justice that are often denied in the primary. Moreover, the sudden turn at the end of story, what Tolkien terms a "eucatastrophe", ensures that the protagonist does not encounter the impending catastrophic doom which seems highly plausible at the moment and offers the reader a piercing glimpse of joy. In Breaking Dawn, when the Volturi came to punish the Cullens by the name of creating an immortal child, the Cullens seemed to be doomed to death, for no coven had survived before. While the Volturi core members were counseling, the fatal confrontation seemed almost inevitable with the Cullens and their friends saying goodbye to their beloved ones. Yet, when Alice returned with the key witnesses who could verify that Renesmee, Edward and Bella's daughter, would not pose a threat to their secret, the Volturi finally decided to leave in peace partly because they did not have any excuse to fight and partly because they were frightened by Bella' incredible shielding power. When this sudden joyous turn comes, the reader can really feel "a catch of breath, a beat and lifting of the heart, near to or accompanied by tears as keen as that given by any form of literary art" (Tolkien, 1965, p. 70).

\section{Utopia}

Utopia, an ideally perfect place, is an "underlying feature of all major modes of fantasy" (Armitt, 2009, p. 113). The term was first coined by Thomas More, and now it often refers to an imaginary place or state of things in which everything is perfect (Crowther, 1999). According to Armitt (2009), "the Utopian impulse- the desire to go 'beyond' - underlies all fantasy writing" (p. 113). The small community formed around Bella by the Cullens and her werewolf friends in the Twilight series also embodies Meyer's imagination of an ideal community in which humanity, family binding and freedom of choice are vital ingredients.

What makes the Cullens distinctive from other vampire covens is their resolution to retain their humanity. To do so, they make the sacrifice resisting the natural instinct of drinking human blood. When asked by Bella why they worked so hard to resist what they were, Edward answered, "Just because we've been dealt a certain hand... it doesn't mean that we can't choose to rise above - to conquer the boundaries of a destiny that none of us wanted. To try to retain whatever essential humanity we can" (Meyer, 2006, p. 307). Their high value for humanity is also shown by their reluctance to create a vampire for their own good. Though lacking a mate for nearly 90 years and falling in love with Bella irreversibly, Edward refused to change Bella into a vampire for fear that Bella would lose her soul while he preferred to kill himself to follow Bella's death instead. 
It is humanity, or what Meyer calls "vampire conscience" (Meyer, 2011, p. 82), that makes the Cullen coven a strong family-style union, the rarest kind in the vampire world. Unlike most vampire covens formed by mates and a few larger ones allied by ambition, the Cullen coven is like a true family, actually a perfect family, perhaps the best people can imagine. As Bella described her life after the transformation:

I was sure my thread must have changed color; I thought it had probably started out a nice beige, something supportive and non-confrontational, something would look good in the background. Now it felt like it must be bright crimson, or maybe glistening gold. The tapestry of family and friends that wove together around me was a beautiful, glowing thing, full of their bright, complementary colors. (Meyer, 2008, p. 525)

Besides the mutual love and support that can be easily felt among the Cullens and within the pack of werewolves throughout the novel, what's more impressive and soul-touching is their firm and indivisible union in the face of two life-threatening crises when they were attacked by the newborn army in Eclipse and the Volturi guards in Breaking Dawn. Such intense family binding depicted in the series is really what everyone longs for but seldom exits in the real world.

Freedom seems to be the integral part of virtually all Utopian societies created in the fantasy fictions and the underlying purpose for all the fights invariably triggered. In The Lord of the Rings, Frodo and his friends made the arduous journey to destroy the ring so as to overthrow the tyrant rule of Dark Lord Sauron and reclaim the peace and freedom in the Middle Earth. Likewise, the final confrontation between the Cullens and the Volturi is indeed the fight to defend their freedom against the domination of the Volturi who hope to seek the death of their free will. The real cause of the Volturi's action is not their uncertainty about whether the hybrid baby will pose a potential threat but their intolerance of what they perceive as competition, and its true purpose is not to protect the safety of their secrecy but to destroy a different way of life. For the Cullens and their friends, they stand together not just to defend the baby, but to defend their freedom of choosing their own way of living just as the questions raised by one of the Cullens' friend "Who rules you nomads? Do you answer to someone's will beside your own? Are you free to choose your path, or will the Volturi decide how you will live" (Meyer, 2008, pp. 718-719) reveal.

\section{Conclusion}

As a typical example of fantasy, one of the most productive and commercially successful of literary genres in English in the second half of the 20th century (Drabble, 2005, p. 350), the Twilight series elicits wonder through elements of the supernatural beyond the ordinary, rationally predictable world, satisfies people's collective inner desires by corresponding to their hidden fears, and eventually liberates readers from the mundanity of everyday life in consumer societies by leading them into the marvelous Secondary World of a Utopian society. Just as Tolkien (2001) puts: Fantasy empowers a storyteller to divorce "green from grass, blue from heaven, and red from blood, cloak him or himself or herself in an enchanter's power, and remixing and creating a new, put a deadly green upon a man's face and produce a horror...cause woods to spring with silver leaves... and put hot fire into the belly of the cold worm...in such fantasy, new form is made; faerie begins; man becomes a sub-creator" (pp. 22-23), the Twilight series conveys a world beyond our own and inspires our imaginations of the impossible.

\section{References}

Armitt, L. (2009). Fantasy fiction: An introduction. Shanghai: Shanghai Foreign Language Education Press. 
Baldick, C. (2008). Oxford dictionary of literary terms. New York: Oxford University Press.

Crowther, J. (1999). Oxford guide to British and American culture. Oxford: Oxford University Press.

Cuddon, J. A., \& Habib, M. A. R. (2014). The Penguin dictionary of literary terms and literary theory. New York: Penguin Reference Library.

Drabble, M. (2005). The Oxford companion to English literature. Beijing: Foreign Language Teaching and Research Press.

Manlove, C. N. (1975). Modern fantasy: Five studies. Cambridge: Cambridge University Press.

Mathews, R. (1997). Fantasy: The liberation imagination. New York: Twayne Publishers.

Meyer, S. (2005). Twilight. New York: Little, Brown and Company.

Meyer, S. (2006). New moon. New York: Little, Brown and Company.

Meyer, S. (2007). Eclipse. New York: Little, Brown and Company.

Meyer, S. (2008). Breaking dawn. New York: Little, Brown and Company.

Meyer, S. (2011). The twilight saga: The official illustrated guide. New York: Little, Brown and Company.

Tolkien, J. R. R. (1965). On fairy-stories. In Tree and leaf. Boston: Houghton Mifflin Company.

Tolkien, J. R. R. (2001). On fairy-stories. In Tree and leaf. London: HarperCollins. 